\title{
THE POSITION AND FINANCING OF HIGHER EDUCATION IN SELECTED INTERNATIONAL DOCUMENTS \\ Zuzana Gálisová $^{1}$, Peter Plavčan ${ }^{2}$
}

\begin{abstract}
This paper presents selected theses on the standing and financing of higher education in three international programming documents on higher education policy: the Bucharest Communiqué of 2012 entitled Making the Most of Our Potential: Consolidating the European Higher Education Area, the Yerevan Communiqué of 2015 and the Paris Communiqué of 2018. The analysis of the standing and financing of higher education includes consideration of the situation in the Slovak Republic.

These three documents consider the standing of higher education in the context of its financing with reference to the function that it fulfils for society in transmitting sophisticated new knowledge to the young generation. There is a visible discrepancy between the expectations of individuals and society as a whole concerning higher education and the sources of its funding. The paper includes an analysis of the changes in stakeholders' views on higher education based on the theses in the three international programming documents on higher education policy.
\end{abstract}

The paper concludes with a synthesis of the knowledge acquired from the three programming documents on higher education policy, and proposals for adding to them.

UDC Classification: 341.1, DOI: https://doi.org/10.12955/pss.v1.48

Keywords: Bucharest Communiqué, Yerevan Communique, Paris Communique, legal regulation, funding of higher education, public, mixed and private goods, impacts of higher education.

\section{Introduction}

The basis for the significant changes in higher education in Europe at the start of the $21^{\text {st }}$ century lay in the Bologna Process recommendations aimed at modernising the field of higher education and science. This modernisation has begun in several areas. Firstly, this concerned a system of comparable stages of study, titles and diplomas, in order to facilitate student mobility between universities and for their diplomas to be more comprehensible for employers in the European area. At the same time, the course of progress in study at higher education institutions was adjusted so that students could at any time during the course of study spend part of it at a different university, in order that they have the possibility to gain experience with a different regime study regime, to get to know students in other countries, and also experience social realities from another country. An essential part of these changes is also that of encouraging teachers to be given the opportunity to gain experience from other schools at home or abroad in the framework of teaching and scientific mobility. All of these changes depend on the volume of funds spent on higher education. In general, it is argued that higher education helps in achieving better application in the labour market, and also has an impact on the social status of young people with higher education because of incomes higher than those of young people with lower education levels. The authors deal with three analyses of the efficiency of education at all levels of the education system in this period, for example (Plavčan, 2019).

In society there is a clearly visible discrepancy between the expectations of individuals and society regarding higher education, and the provision of resources for financing it. Many times, modernisation is more taken to mean reducing public funding and seeking possibilities for multi-sourced funding, which ultimately results in the university student's participating in financing their study. The main research issue in this paper is the analysis of attitudes of one of the main actors in higher education, and their changes with regard to the social situation in the European Higher Education Area in selected higher education policy programming documents, namely the Communique of Ministers Responsible for Higher Education. The same particular topic is also presented in the view of higher education in the Slovak Republic with regard to selected school policy programming documents.

\section{Bucharest Communique (2012)}

On 26 and 27 April 2012, ministers responsible for higher education from 47 countries of the European Higher Education Area met in Bucharest, at the time of the financial crisis. Ministers in their communique characterised the situation as follows: "Investing in higher education for the future Europe is undergoing an economic and financial crisis with damaging societal effects. Within the field of higher education, the crisis is affecting the availability of adequate funding and making graduates' job prospects

\footnotetext{
${ }^{1}$ Pan-european University, Bratislava, Slovakia. zgalisova@gmail.com

${ }^{2}$ Danubius University, Sládkovičovo, Slovakia. peter.plavcan@vsdanubius.sk
} 
more uncertain. Higher education is an important part of the solution to our current difficulties. Strong and accountable higher education systems provide the foundations for thriving knowledge societies. Higher education should be at the heart of our efforts to overcome the crisis - now more than ever. With this in mind, we commit to securing the highest possible level of public funding for higher education and drawing on other appropriate sources, as an investment in our future. We will support our institutions in the education of creative, innovative, critically thinking and responsible graduates needed for economic growth and the sustainable development of our democracies. We are dedicated to working together in this way to reduce youth unemployment" (Bucharest Communique, 2012).

The ministers responsible for higher education pointed out that investment in higher education is an investment in Europe's future, and this particularly at the time of a financial crisis that is having damaging social effects in national states. At the time of the financial crisis, public spending is reduced, negatively impacting on national funding for higher education in national states, resulting in less access to higher education for young people. For university graduates, the period of the financial crisis also means uncertain prospects of finding appropriate employment, or even employment at all.

Ministers stated in their communique that higher education funding is one of the solutions to overcoming the current financial crisis and should be part of the essence of efforts to overcome it. For this reason, the ministers responsible for higher education in their Bucharest Communique commit to ensuring in their national states the highest possible level of public funding for higher education and to seek other appropriate sources for funding it. Ministers also expressed their support for universities in preparing innovative and creative graduates with critical thinking, who are needed for economic growth and the sustainable development of democracy. The foresight of ministers responsible for higher education regarding the requirement for developing young people's critical thinking in connection to the major changes in national states' social systems deserves attention. They also pointed to the thesis that higher education brings its bearer better employment in the labour market.

Ministers responsible for higher education further state that "we will strive for more coherence between our policies, especially in completing the transition to the three cycle system, the use of ECTS credits, the issuing of Diploma Supplements, the enhancement of quality assurance and the implementation of qualifications frameworks, including the definition and evaluation of learning outcomes. We will pursue the following goals: to provide quality higher education for all, to enhance graduates' employability and to strengthen mobility as a means for better learning" (Bucharest Communique, 2012).

The communique places emphasis on the principles of the Bologna process and their implementation in the individual countries of the European Higher Education Area. These principles should result in improving the quality of higher education and raising graduates' employment. To this end, to give young people crosscutting, multidisciplinary and innovative knowledge and enabling them to develop personally and professionally throughout their working life. As the communique states: "Lifelong learning is one of the important factors in meeting the needs of a changing labour market, and higher education institutions play a central role in transferring knowledge and strengthening regional development, including by the continuous development of competences and reinforcement of knowledge alliances" (Bucharest Communique, 2012).

\section{Yerevan Communique (2015)}

On 14 and 15 May 2015, ministers responsible for higher education met in Yerevan, noting with pride the creation of a higher education area of 47 countries on the basis of open dialogue, common objectives and commitments. As they say in their communique: "Together we are engaged in the process of voluntary convergence and coordinated reform of our higher education systems. This is based on public responsibility for higher education, academic freedom, institutional autonomy, and commitment to integrity. It relies on strong public funding, and is implemented through a common degree structure, a shared understanding of principles and processes for quality assurance and recognition, and a number of common tools" (Yerevan Communique, 2015).

The introductory principles of the communique highlight two facts. The communique states the public responsibility for higher education, meaning that ministers responsible for higher education remain on the higher education platform as an area of major social priorities, while building on the theses of the 2012 Bucharest Communique. Furthermore, the ministers responsible for higher education in the communique states that the creation and development of the European Higher Education Area relies on 
strong public funding, thus ensuring the continuation of the platform of the state's responsibility for developing and funding higher education as a means of accelerating social development and concurrently as a means for young people to enter the domestic, as well as European labour market. The communique does not mention specifically the financial crisis, which, in the 2012 Bucharest communique was one of the arguments for funding higher education from public sources. It describes the current state of society as follows: "Today, the EHEA faces serious challenges. It is confronted with a continuing economic and social crisis, dramatic levels of unemployment, increasing marginalisation of young people, demographic changes, new migration patterns, and conflicts within and between countries, as well as extremism and radicalisation. On the other hand, greater mobility of students and staff fosters mutual understanding, while rapid development of knowledge and technology, which impacts on societies and economies, plays an increasingly important role in the transformation of higher education and research" (Yerevan Communique, 2015).

The main reasons for investing in higher education are mainly the introductory role of the European Higher Education Area, based on collaboration in higher education and science, mobility of students, teachers and researchers, and creating a European citizenry, innovation and employment.

Ministers responsible for higher education expressed their support for raising the employability of higher education graduates during their working life, either by promoting new job opportunities or supporting their self-employment. As the communique states: "We need to ensure that, at the end of each study cycle, graduates possess competences suitable for entry into the labour market which also enable them to develop the new competences they may need for their employability later in throughout their working lives. We will support higher education institutions in exploring diverse measures to reach these goals, e.g. by strengthening their dialogue with employers, implementing programmes with a good balance between theoretical and practical components, fostering the entrepreneurship and innovation skills of students and following graduates' career developments" (Yerevan Communique, 2015).

To this end, the Ministers responsible for higher education undertook to create conditions for the recognition in their countries of different qualifications, including those acquired in short study cycles, even if they do not exist in their own systems. The Yerevan communique commitments also include the issue of loans for university students and the requirement of their portability with the student.

\section{Paris Communique (2018)}

On 24 and 25 May 2018 ministers responsible for higher education met in Paris and celebrated not just progress in building the European Higher Education Area, but also adopted strong and ambitious commitments to develop it further.

The ministerial conference was held in a period of world economic growth, which was also reflected in the content of communiques approved by the attending ministers responsible for higher education. The communique states: "At a moment when Europe is facing important societal challenges - ranging from unemployment and social inequality to migration-related issues and the rise in political polarisation, radicalisation and violent extremism - higher education can and must play a decisive role in providing solutions to these issues. It must also play a key role in establishing the facts on the basis of which public debates are conducted and decisions made. By providing students and other learners with opportunities for lifelong personal development, higher education enhances their prospects of employment and stimulates them to be active citizens in democratic societies. We therefore commit to developing policies that encourage and support higher education institutions to fulfil their social responsibility and contribute to a more cohesive and inclusive society through enhancing intercultural understanding, civic engagement and ethical awareness, as well as ensuring equitable access to higher education" (Paris Communique, 2018).

The Paris Communique of the Ministers responsible for higher education contains only one social theme from the area of public responsibility for higher education, namely the unemployment of university graduates. There is no mention of two key topics from the previous communiques in Bucharest and Yerevan, namely the state's responsibility for higher education funding and the strong public funding of higher education.

The Paris Communique of the ministers responsible for higher education confirms the thesis from the previous communiques from Bucharest and Yerevan on the importance of young people's higher education as a prerequisite for greater prospects for gaining appropriate employment and also as a 
stimulus to be an active citizen in a democratic society. This is an important prerequisite for enhancing intercultural understanding, civic engagement and moral awareness.

The Paris Communique of ministers responsible for higher education extends the themes of recognition of qualifications beyond those of the preceding two communiques, in response to the changed situation in European countries, following the waves of migration. It is proposed to further work on the automatic recognition of comparable qualifications for the purposes of further study and entry into the labour market. It is necessary to address the recognition of migrants' qualifications, and also forms of digital education. For addressing the recognition of results in short cycles of education, the communique states: "In many of our systems, ECTS-based short cycle qualifications play an increasingly important role in preparing students for employment and further studies as well as in improving social cohesion by facilitating access for many who would otherwise not have considered higher education. We are therefore including short-cycle qualifications as a stand-alone qualification within the overarching framework of qualifications of the EHEA (QF-EHEA). Each country can decide whether and how to integrate short cycle qualifications within its own national framework" (Paris Communique, 2018).

The impact of economic growth on the countries of the European Higher Education Area was also reflected in the text of the Paris Communique. The topic of social responsibility for higher education is stated in this document, based mainly on improving the quality of higher education, seeking opportunities to facilitate labour mobility by simplifying qualifications recognition procedures, and the topic of the arrival of migrants in the recognition of their qualifications acquired in another education environment.

\section{Selected theses on the financing of higher education in the Slovak Republic}

In the Slovak Republic, over the period preceding the three international communiques and during their approval there were the following amendments to legislation in the area of higher education funding. The Higher Education Act of 1999 prescribed tuition fees for students exceeding the standard length of study, and for external study. Amendments to the Higher Education Act from 2003 and 2005 brought some precision to the issue in legislative provisions on tuition fees, which for the first time became income of the higher education institution, and then it's revenue, with subsequent legal amendments fine tuning this legislation. Since the introduction of legislation in the 1990s providing for private higher education institutions, they have had no claim to receive funding from the state budget, unless they give consent to the representation of higher education institutions. A specific feature of public higher education in the Slovak Republic is that funds from business activity are obtained prevailingly from tuition fees from students, and minimally from other business activities in the field of providing other services, e.g. training and other activities of a similar type for the public and private sector, business activities in research, project development, etc.

\section{Conclusion}

In this paper we have analysed the international programming documents of European education policy from the aspect of the main social topics, especially the funding of higher education, and have covered certain knowledge of the development of legislation in the Slovak Republic at the start of the $21^{\text {st }}$ century. The analysis of international documents affecting educational policy and labour mobility policies is of great importance in the current period of major social changes in Europe and the world. For example, the Marrakech Compact looks for effective solutions to how to help migrants get involved in the European labour market, in the context of the migration crisis (Moška, Plavčan, 2019). In this issue, it is essential to provide the public truthful information on the sensitive, but very important topics affecting the thinking of large parts of the population in European countries (Plavčan, Funta, 2019).

Three communiques of ministers responsible for higher education address sources of funding for higher education in connection with the development of European society and its economy. In a period of continuing and partially fading global financial crisis, the Bucharest Communique (2012) and the Yerevan Communique (2015) set out in some detail to major societal themes for securing funding for higher education and for strong public funding of higher education. The Paris Communique (2018) contains only one common theme from the field of public responsibility for higher education, namely that of graduate unemployment.

At the beginning of the $21^{\text {st }}$ century, state authorities in the Slovak Republic reacted similarly in amending legislation concerning higher education funding. After the initial financial burden placed on 
those studying in 1999 for exceeding the standard length of study, and pursuing external study, there came the period of the first decade of the $21^{\text {st }}$ century in which tuition fees became the revenue of higher education institutions. During the financial crisis and its aftermath, there were no fundamental changes in legislation in the area of higher education funding in the Slovak Republic. Discussions on this topic are sporadic, but still ongoing.

Theoretical examination of education policy documents, legislation and an insight into the education economy, and education itself, can provide a significant contribution to greater transparency in the legislative changes in this field. Moreover, they can contribute to bringing objectivity to funding of higher education with regard to the state of the economy and social status of the population.

\section{References}

Bucharest Communiqué. (2012). Retrieved from http://ehea.info/page-the-bologna-follow-up-group

Funta, R. (2011). Economic Law and Economic Crisis. Where do we go from here? Economic, Legal and Political dimension. Danube Law and Economic review, Issue 1, pp. 65-71. ISSN 1804-6746

Moška, M., Plavčan, P. (2019). Global Compact for Safe, Orderly and Regular Migration (Marrakech, Morocco) - Some Comments. European Law Journal, (1), p. 24-27. Retrieved from http://www.eulawjournal.eu/articles/EU_LAW_JOURNAL_1_2019.pdf

Paris Communiqué. (2018). Retrieved from http://ehea.info/page-the-bologna-follow-up-group

Plavčan, P. (2019). The comparison of PISA educational results with gross domestic product in member states of European Union. Prague: International Conference on Innovations and Science education, March 20-22, 2019. Journal Contact. Print. ISSN 1805-997X, Online ISSN 1805-9961

Plavčan, P., Funta, R. (2019). Údaje a ich úloha v politických kampaniach? [Data and their role in political campaigns?]. Justičná revue, (10), p. 934-957. ISSN 1335-6461

UNESCO. (1945). UNESCO Constitution. Retrieved from http://portal.unesco.org/en/ev.php-

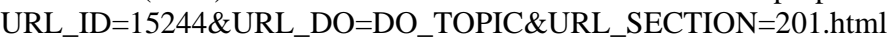

Yerevan Communiqué. (2015). Retrieved from http://ehea.info/page-the-bologna-follow-up-group 